\title{
ALKALOIDS OF Glaucium elegans
}

L. D. Yakhontova, O. N. Tolkachev,

UDC 547-94 and Yu. V. Baranova

Continuing a study of the plants of the genus Glaucium, we have investigated the alkaloid composition of Glaucium elegans, family Papaveraceae.

It is known that this plant contains alkaloids of the aporphine group (glaucine, isoboldine, isocorydine, corydine), of the protopine group (protopine, allocryptopine), and the benzophenanthridine group (chelidonine, sanguinarine, chelerythrine, and chelirubine) $[1,2]$.

The herbage of Glaucium elegans was collected in the Ashkhabad oblast of the Turkmen SSR in 1973 in the vegetation period. By the dichloroethane method, the epigeal part yielded $0.24 \%$ of combined alkaloids, the separation of which on alumina [3] gave, in addition to the alkaloids mentioned above, the oxidized aporphine alkaloids O-methylatheroline and glauvine, the presence of which in Glaucium elegans has not been reported previously.

The benzene solutions after the separation of the glaucine, the amount of which in this plant was $0.08 \%$, yielded yet another base, sparingly soluble in methanol. After recrystallization from methanol-chloroform, this base had $\mathrm{mp} 164-165^{\circ} \mathrm{C}$ and the composition $\mathrm{C}_{21} \mathrm{H}_{19} \mathrm{NO}_{4}$, mol. wt. 349 (mass spectrometrically). UV spec-

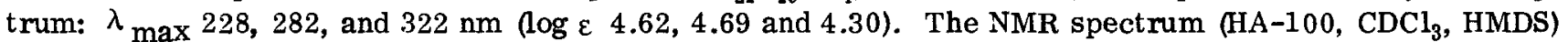
had the three-proton singlet of an $\mathrm{NCH}_{3}$ group $(2.51 \mathrm{ppm})$, two three-proton singlets of $\mathrm{OCH}_{3}$ groups $(3.79$ and $3.82 \mathrm{ppm})$, the signal of a $\mathrm{CH}_{2}$ group $(4.22 \mathrm{ppm}, \mathrm{s}, 2 \mathrm{H})$ and of a $\mathrm{CH}_{2} \mathrm{O}_{2}$ group $(5.94 \mathrm{ppm}, \mathrm{s}, 2 \mathrm{H})$, one-proton singlets in the aromatic region (7.02 and $7.59 \mathrm{ppm})$, and the signals of two pairs of aromatic ortho protons $(6.84$ and $7.61 \mathrm{ppm}, J=8 \mathrm{~Hz}$, and at 7.37 and $7.41 \mathrm{ppm}, J=8 \mathrm{~Hz})$.

From its physicochemical properties, elementary composition, and UV and NMR spectra, the base that we isolated corresponds to the known alkaloid dihydrochelerythrine, which has been isolated from Argemone mexicana L. [4]. For comparison, dihydrochelerythrine was obtained from chelerythrine by its reduction with $\mathrm{NaBH}_{4}$ in methanol. The results of a direct comparison of the base from Glaucium elegans and dihydrochelerythrine (absence of a depression of the melting point of a mixture, coincidence of their IR spectra) showed that this base is dihydrochelerythrine. viously,

The presence of dihydrochelerythrine in plants of the genus Glaucium has not been described pre-

\section{LIT ERATURE CITED}

1. J. Slavik, Collection Czech. Chem. Commun., 25, 1698 (1960).

2. L. Slavikova, Collection Czech. Chem. Commun., 33, 635 (1968).

3. L. D. Yakhontova, Lekarstv. Rast., 15,348 (1969).

4. L. Slavikova and J. Slavik, Collection Czech. Chem. Commun., 21, 211 (1956).

All-Union Scientific-Research Institute of Medicinal Plants. Translated from Khimiya Prirodnykh Soedinenii, No. 5, p. 686, September-October, 1973. Original article submitted May 3, 1973. 